\title{
PERSONAL ORGANIZATIONAL WELL-BEING AND QUALITY OF ORGANIZATIONAL LIFE: THE MEDIATING ROLE OF ORGANIZATIONAL CULTURE
}

\author{
MARIA G. T. PAZ ${ }^{1}$ \\ (iD) https://orcid.org/0000-0003-0992-7139 \\ SONIA R. P. FERNANDES ${ }^{2}$ \\ (iD) https://orcid.org/0000-0001-6426-5452 \\ LAILA L. CARNEIRO ${ }^{2}$ \\ (iD) https://orcid.org/0000-0001-7183-0501 \\ ELEUNÍ A. A. MELO 3 \\ (iD) https://orcid.org/0000-0002-9527-421X
}

To cite this paper: Paz, M. G. T., Fernandes, S. R. P., Carneiro, L. L., \& Melo, E. A. A. (2020). Personal organizational well-being and quality of organizational life: The mediating role of organizational culture. Revista de Administração Mackenzie, 21(1), 1-37. doi:10.1590/1678-6971/ eRAMD200122

Submission: June 15, 2019. Acceptance: Oct. 23, 2019.

1 Universidade de Brasília (UnB), Brasília, DF, Brazil.

2 Universidade Federal da Bahia (Ufba), Salvador, BA, Brazil.

3 Outside Consultant, Brasília, DF, Brazil.

\section{(cc) BY




\section{ABSTRACT}

Purpose: To test models of mediation and moderation of the organizational culture, competing values and styles of organizational operation having quality of organizational life (QOL) as antecedent and personal organizational well-being (POW) as consequent.

Originality/value: Literature has presented tests of mediation/moderation models to understand well-being of employees and support leadership in the implementation of strategies that fit into the organizational realities. Organizational culture has been used as a component variable of some of those models. However, no publication investigating culture as mediator/moderator of the quality of life/well-being relation was found.

Design/methodology/approach: Quantitative, transversal survey employing scales that present evidences of psychometric validity applied to 1,292 employees $(81 \%)$ of the population in a public organization. Two mediation models and two moderation models were tested through multiple regression.

Findings: The results of the linear and hierarchic regression analyses used to test the proposed models showed that, except for the bureaucratic culture, all types of culture had significant power of mediation between the variables of QOL and POW. No moderation relation was found. The empirical evidences of the models tests point out the need for considering cultural traits of organizations in the design of strategies of intervention related to QOL and POW, since some may be more applicable to given cultures and less applicable to others.

\section{KEYWORDS}

Quality of organizational life. Well-being. Culture. Mediation. Model. 


\section{INTRODUCTION}

Currently, health, well-being, rights, social justice, decent work and human dignity are important focuses of debate. However, as early as in 1948, the United Nations (UN) already considered work as a right of all human beings, and the International Labour Organization (ILO) (1981) set rules for safety and health of employees in different contexts.

Organizations are one of the more visible work contexts to the society. Therefore, the commitment towards sustaining environments favorable to the organizational collectivity should be brought to organizational contexts. The commitment to understand the organizational systems and processes that facilitate or hinder the promotion of employee well-being is crucial. This is the core focus of the study.

Firstly, it approaches the personal organizational well-being (POW) based on the concept of "person" as the individual vested with a social role (Guareshi, 2002), here playing a role in a given organizational context. Next, it approaches the quality of organizational life (QOL) as a responsibility of the leadership, but not disregarding the active participation of employees. In line with the United Nations Development Programme (UNDP) (2005) propositions, employees are holders of rights, rather than beneficiaries of actions. This proposition is based on relations of reciprocity between the individual and the organization.

To better understand quality of life and promotion of well-being in the context of organizations, one should also characterize the dynamic of their operations or, at least, some of their processes or systems. Here, organizational culture is approached as a system to be considered when implementing policies, guidelines and actions on behalf of employees that, in turn, commit to the fulfillment of goals, the survival and the growth of the organization.

The organization members bring into their contexts the values transmitted and strengthened in the family and educational learning processes. Through intersubjectivity, they fit these values to build ways of feeling, thinking and acting that are shared in organizations. This is the concept of organizational culture adopted in the study. The purpose of this study is to establish relations between well-being, quality of life and organizational culture.

\section{PERSONAL ORGANIZATIONAL WELL-BEING}

The construct well-being has been object of studies and research focused on understanding the phenomenon, thus, supporting the formulation of 
public policies in addition to organizational policies and guidelines, to favor the happiness of people in many dimensions of their lives.

Several surveys on well-being also focus on the phenomenon in an overall light, like in the early investigations about it, and do not characterize it in specific contexts. There are two lines: that of subjective well-being and that of psychological well-being. The subjective well-being derives from the hedonist tradition that considers more frequently the positive affects, emotions and humors (Diener, 1984, 2000). The psychological well-being, in turn, has its origin in the eudaimonic view that emphasizes self-fulfillment (Ryff, 1989, 2014). Based on both approaches, some authors started investigating well-being in specific contexts, including the work context (Van Horn, Taria, Scchaufeli \& Scheurs, 2004; Warr, 1987, 2007).

Van Horn et al. (2004) approach the occupational well-being that refers to the positive evaluation of work factors. Warr (2007), in turn, considers that work environment influences the individual well-being that depends on to which extent the environment provides them with opportunities of positive experiences only if these opportunities are perceived and seized.

Other surveys have been developed approaching well-being, both in general light and in different contexts, including the work context. Much of the publications depict the concern about conceptualizing the construct and designing measurement instruments corresponding to the theoretical approaches adopted. The instruments to measure well-being are still under construction, more specifically to given contexts, such as studies like that by Bartels, Peterson, and Reina (2019) that built and identified indicators of validity of an eudemonic scale of well-being in the workplace to test the impact of bullying in the well-being of nurses.

A review of literature shows that researchers understand well-being at work/in organizations based on different theoretical concepts that affect the empirical studies. The theoretical concept by Paz (2011) adopted in this study defines POW as the fulfillment of needs and desires of individuals when playing their roles in organizations, assuming a relation of reciprocity between the individual and the organization. The two dimensions shown in Figure 3.1 are considered to evaluate it: professional fulfillment and work conditions. The Scale of Personal Organizational Well-Being (SPOW) is the instrument that measures the phenomenon. The scale items describe personal well-being indicators restrict to the organizational environment. Other surveys are developed applying this approach (e.g. Carneiro \& Fernandes, 2015).

Although the analysis of publications on well-being suggests the inexistence of consensus about the definition of the phenomenon, Shulte 
and Vainio (2010) emphasize the agreement about the perception of wellbeing as more than the lack of negative factors in the different approaches. Another consideration is that well-being is related to positive behaviors and refers to a subjective state that is more important and beneficial to the individual than to the organization (Juniper, Bellamy, \& White, 2011). According to Sonnentag (2015), well-being is a mutable phenomenon that suffers more or less slight fluctuations, both in short and long periods of time. This reveals dynamicity.

The development of new studies on this topic has changed the scenario, and the range of topics and relations between variables in research has expanded. One of the material issues refers to the emphasis placed on the construction of the well-being process. In 2000, Diener underlined that the focus of studies about well-being should be on when and why people are happy, and which processes influence well-being. He also warns that studies should incorporate in their core the understanding of well-being jointly with its indicators.

In 2014, Hillage, Brown, Shiels, and Gabbay stated that the process of building well-being should comprise the organization's guidance and support to the employee towards adopting a life style capable of ensuring their mental health, as well as proactive actions of the organization, such as offering fair treatment to employees, appraising and recognizing them, among others. Based on the systematic review of meta-analytic studies, the authors point out positive evidences to the effectiveness of organizational interventions that expand the employee's participation.

The advances of studies on well-being not only aim at understanding and defining the construct and understanding the dynamic of the construction of the well-being construct, but also to simultaneously test models that establish relations between the personal dimension, dimensions of the work environment and even the context wherein the organization is inserted.

In this sense, the investment in and research on training raise to ensure well-being in organizations. In a systematic review of resilience training, Robertson, Cooper, Sarkar, and Curran (2015) showed that this kind of training enhances personal resilience and the indicators of mental health and the subjective well-being. Many other trainings have been developed in this light; however, not all are tested for the effective generation of positive impacts. Process analysis is important to assess intervention programs focused on the employee well-being, i.e., the responsiveness of the intervention objectives and effectiveness. Biron, Karanika-Murray, and Cooper (2012) point out that the poor quality of the studies that evaluate 
most interventions, allied to the little attention given to the aspects of the process, could adversely affect the success of programs, despite their sound theoretical grounds.

Guest (2017) suggests human resources management practices that ensure increased well-being: investment in employees - training and development; positive physical and social environment; use of voice allowing everyone's voice, among others. According to Cooper, Yipenge, and Tarba (2014), there is a need for theories and research about support to well-being assisted by the HR management area, considering the globally increased competitiveness and the advance of technologies in the age of information. Organizations are pressed to meet productivity goals, among others, and this generates negative impact on health, well-being and performance at work.

Literature on well-being points out two dimensions that appear as related: one is the subjective dimension that characterizes well-being, and the other is the context dimension that refers to the quality of the environment. Both dimensions have been approached by studies on wellbeing and those on quality of work life variable, variable to be approached in the next topic.

\section{QUALITY OF LIFE IN THE CONTEXT OF WORK}

Historically, through different theoretical approaches, the literature on this topic - quality of work life (QWL) - has pointed out some incongruence and conceptual limitations. Therefore, literature points at two perspectives to review the phenomenon: one that associates QWL to the organizational perspective that incorporates a set of contextual conditions that impact the employee well-being, and another one that emphasizes to which extent the employees' personal needs are fulfilled. Elyzur and Shye (1990) draw attention to these two perspectives, and emphasize the need for differentiating the quality of life experienced by the individual and the conditions of the environment in which the work is performed, known as quality of the work environment. It is worth mentioning that publications in this field have pointed out the trend towards integrating both perspectives, so that QWL is characterized as a construct that incorporates objective and subjective measures (Hannif, Burguess, \& Cornell, 2008).

Walton's (1973) theoretical model is a highlight among the theoretical models used in QWL, presenting the QWL dimensions as variables of context that, in practice, are under the responsibility of leadership. The author 
proposed one of the most known models up to now. The model defines QWL as the concern of an organization about humanistic and environmental values, considering eight essential and comprehensive criteria to achieve it: 1. adequate and fair compensation; 2 . safe and healthy working conditions; 3. opportunity to use and develop human capacities; 4 . opportunity to growth and security; 5 . social integration in the work organization; 6 . constitution in the work organization 7. work and total life span; and 8. social relevance of work life. Working with QWL indicators similar to those of Walton's, the studies by Nanjundeswaraswamy and Swamy (2015), by Swamy, Nanjundeswaraswamy, and Rashmi (2015), and by Akter and Banik (2018), among others, support that Walton's model remains valid.

QWL models are being added to literature. The systemic model of QWL of Boas and Morin (2017) considers work organization as central, and incorporates individual variables as elements that will affect the work meaning to employees, in addition to the evaluation of organizational practices. Campos and Rueda (2017) analyze the effects of organizational values on QWL and point out that organizations should get the values declared closer to the values practiced, envisioning this relation of congruence as a QWL indicator.

Based on Walton's (1973) model, Ribeiro, Paz, Caldas, and Santos (2012) proposed the concept of QOL restrict to organizations. This concept refers to positive and healthy organizational environments that enable the well-being of its components, with five dimensions (Figure 3.1). This is the concept adopted in this study. It focuses on the quality of life of the collectivity and that is why they approach QOL as a responsibility of leadership.

This study assumes that QOL, variable of context, and POW, individual variable, are dimensions of the QWL understood as a bigger unit of analysis that incorporates the context of organizational work and other contexts of work (Figure 3.1). 


\section{(Figure 3.1)}

\section{CONCEPT OF QWL BASED ON THE VARIABLES OF QOL (CONTEXTUAL) AND POW (INDIVIDUAL) AND THEIR RESPECTIVE DIMENSIONS}

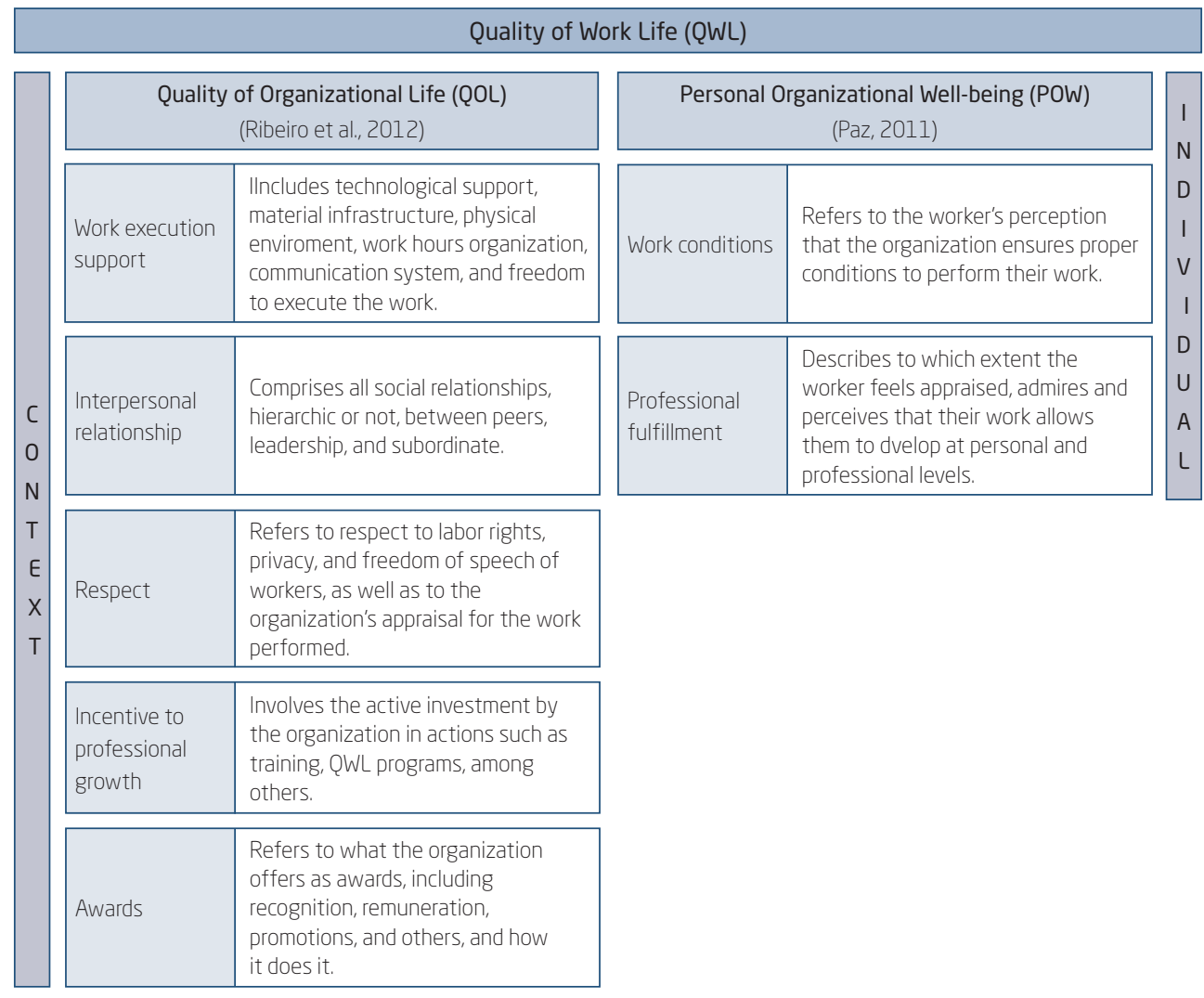

Source: Elaborated by the authors.

The literature on the topic raises interest in testing the most robust models in the establishment of relations between both variables. One could hypothesize, for example, that some organizations will be more successful in the management of some QOL dimensions, while others will manage other dimensions better. Therefore, some organizational features that could enable or hinder the QOL and, thus, the POW should also be considered. The culture of the organization is a variable at the organizational level that could affect this relation. 


\section{ORGANIZATIONAL CULTURE}

The identification of the organizations' cultural profile proved to be one of the main tools to manage the organizational context, and has inspired a huge amount of studies aimed at better understanding the relation between culture and management. According to Quinn, Faerman, Thompson, McGrath, and Clair (2011), the organizational culture should be considered as a lens that help understanding and diagnosing the effectiveness of an organization's project. Therefore, taking the organizational culture and subcultures traits into consideration seems to be crucial to implement polices, guidelines and programs on quality of life in those contexts.

The organizational culture has been the component variable of some mediation and moderation models that correlate personal and organizational variables. However, no publication that directly investigates culture and its relation with the quality of the work environment and well-being was found. Some studies that most closely approximate to this relation are presented below.

Considering the literature indications that personal and organizational variables could be mediator/moderator of the employee well-being, Dessen and Paz (2010) investigated the impact of the organizational power setups on the POW, with mediation of personality traits. Results showed positive correlations between autonomous and missionary culture and well-being, and negative correlation between instrument culture and well-being. The last two relations are mediated by the conscientiousness personality trait. Choi, Oh, and Colbert (2015) have analyzed the relation between personality traits, organizational commitment, and individualist and collectivist culture of the society in which the organization was inserted. To that, they performed a meta-analysis with a sample of 50 studies that, in the moderation test, showed that the relation between personality traits and commitment is strengthened in individualist cultures. Pilch and Turiska (2015) tested a moderation model having culture as the antecedent variable. Here, culture was represented by Camaron's and Quinn's (1999) competing values, having as moderator variable the Machiavellianism, approached as domination, and as criterion variable bullying, approached as intimidation. Results suggested that intimidation is negatively related to the clan and adhocracy cultures, and positively related to hierarchic cultures. Machiavellianism is a significant moderator of the clan and hierarchy cultures and intimidation. Schneider, Ehrhart, and Macey (2013), analyzing the annual review on organizational 
climate and culture, point out the need for incorporating cultural variables as moderators in the models of research in organizational behavior.

This study adopts Schein's (1992) concept of culture, according to which culture consists in ways of feeling, thinking and acting that are shared by the organization members, and considered right and undisputed. Subcultures are also emphasized and identified when the perceptions on some elements are shared only by given groups or specific areas. The author considers three levels of analysis, and two of these are incorporated in this research: basic values and assumptions. Two variables are considered as representative of culture: competing organization values - COV (Cameron and Quinn, 1999), approached based on indicators of the organization effectiveness, and organizational styles of operation - SOS (Paz \& Mendes, 2008), level of basic assumptions, approached based on the symbolic relations that individuals establish with their organizations (Figure 4.1).

\section{(Figure 4.1)}

\section{APPROACHES OF THE ORGANIZATIONAL CULTURE: COMPETING VALUES AND ORGANIZATIONAL STYLE OF OPERATION}

\begin{tabular}{|c|c|c|c|}
\hline \multicolumn{4}{|c|}{ Organizational culture } \\
\hline \multicolumn{2}{|c|}{$\begin{array}{l}\text { Competing Organizational Values (COV) } \\
\text { (Cameron \& Quinn, 1999; Quinn et al., 2011) }\end{array}$} & \multicolumn{2}{|c|}{$\begin{array}{l}\text { Organizational Style of Operation (OSO) } \\
\text { (Paz \& Mendes, 2008) }\end{array}$} \\
\hline Clan culture & $\begin{array}{l}\text { Emphasizes participation, openness, } \\
\text { commitment, and moral. Collaborate is the } \\
\text { word that best describes it. }\end{array}$ & $\begin{array}{l}\text { Individualist } \\
\text { culture }\end{array}$ & $\begin{array}{l}\text { Most people shows narcissistic features } \\
\text { and, through intersubjectivities, give the } \\
\text { individualist tone of the organizational } \\
\text { operation. }\end{array}$ \\
\hline $\begin{array}{l}\text { Hierarchy } \\
\text { culture }\end{array}$ & $\begin{array}{l}\text { Emphasizes documentation, information } \\
\text { management, stability, and control. Control } \\
\text { is the word that best describes it. }\end{array}$ & $\begin{array}{l}\text { Affiliative } \\
\text { culture }\end{array}$ & $\begin{array}{l}\text { People are characterized by the need of } \\
\text { belonging to a group, appraise union, and } \\
\text { cohesion. }\end{array}$ \\
\hline $\begin{array}{l}\text { Adhocracy } \\
\text { culture }\end{array}$ & $\begin{array}{l}\text { Emphasizes innovation, fitting, growth, } \\
\text { and acquisition of resources. Create is the } \\
\text { word that best describes it. }\end{array}$ & $\begin{array}{l}\text { Bureaucratic } \\
\text { culture }\end{array}$ & $\begin{array}{l}\text { People appraise stability, security, and } \\
\text { discipline ensured to them by a strong } \\
\text { system of rules and regulations. }\end{array}$ \\
\hline Market culture & $\begin{array}{l}\text { Emphasizes productivity, fulfillment, } \\
\text { direction, clear goals. Compete is the word } \\
\text { that best describes it. }\end{array}$ & $\begin{array}{l}\text { Entrepreneurial } \\
\text { culture }\end{array}$ & $\begin{array}{l}\text { People are innovative, appraise } \\
\text { well-established collaborative } \\
\text { relationships, and professional interaction. }\end{array}$ \\
\hline
\end{tabular}

Source: Elaborated by the authors.

As this study analyzed a public organization, market culture was replaced by society culture. Paz, Melo, Tonet, and Villa (2014) propose a review of the name, definition and items of the market factor when the emphasis of the organization is the market culture, but oriented to the society. They are 
driven by results and achievements, compete with each other to be a highlight among the institutions in their industry, and are interested in the achievement of organizational objectives translated into social results.

To understand the dynamicity of the relations between QOL, culture and POW it is worth emphasizing that the QOL proposal approached in the survey takes into consideration the different dimensions of the construct as management policies. These are policies common to all organizations, with different emphases derived from the organization mission and, therefore, of the products it delivers to the society or groups of the society. Any organization that needs competing in the market with other organizations of the same size to fulfill its mission could attach more importance to providing its employees with consistent support to perform their tasks than on relational issues, for example (where "support to the execution of tasks" and "interpersonal relation" are two dimensions of QOL). To achieve results coherent with its mission, the organization consistently builds a system of competitive values.

According to Schein (1992), policies come up when the organization is created, by decision of the founders, and precede culture that is built through the interaction of organizational members and become identity when the ways of feeling, thinking and acting are shared. Every organization has its unique cultural identity. Culture represents the best way of interaction of groups, including organizations, and cultural coherence implies adequacy of the organization culture-mission, organizational culture-policies, cultureprocesses, etc. (Quinn et al., 2011) that give rise to well-being.

Organizational culture and policies are macro dimensions and, since the organizational context is characterized by dynamicity, these variables of organizational behavior could influence one another. Cultures change and, in this processes of change, they may be deprived from their features, become fluid, and leaderships try to reconstruct them. Most of the contexts with these features get through crisis by adopting new cultural patterns or retaking previous patterns that are now strengthened (Mintzberg, 1983). However, the implementation or strengthening of management policies and strategies is what ensures that the organization gets back to the path of the previous culture, or follows the paths of cultural change, seeking for productivity and promotion of the well-being of its components. Thus, one can assume that sometimes the management policies, here understood as dimensions of the QOL, influence and are influenced by culture. When cultural coherence exists, culture is a structuring element of the organization identity and sets the tone for its operation. With a turbulent macro context as today, with 
constant demands for changes in organizations (Sousa-Silva, 2003), the mutual influence culture-policies of QOL is becoming more intensive.

In this survey we propose the incorporation of cultural types in the models of investigation as moderator and mediator variables, having QOL as antecedent and POW as consequent. As moderators they can change the direction and/or strength of the relation between QOL and POW. Therefore, in the presence of the adhocracy culture as moderator, for example, the intensity of the relation between the QOL dimension of awards and the POW dimension of professional fulfillment would be increased or decreased, in positive or negative direction. In this example, one could expect an increase on intensity in a positive direction, as this culture values well-established relations of exchange. As mediators, the cultural types, in turn, would promote a reduction of the impact of QOL on POW. The QOL affects POW through culture, the third variable of the relation. Thus, in the presence of the adhocracy culture as mediator, for example, the impact of awards on fulfillment would be reduced in magnitude, but the power of explanation about fulfillment would increase. A result of this nature would be reasonable as it is about culture with utilitarian values.

There are few surveys with culture as moderator and mediator variable, and that is why this study was developed. It should be identified if organizational culture mediates and moderates the relations between antecedent and consequent variables of the organizational behavior.

Specifically, it intended to verify:

1) if the COV can change the direction and intensity of the relation between QOL and POW;

2) if the OSO can change the direction and intensity of the relation between QOL and POW;

3) if the COV mediates the QOL-POW relation, reducing the impact of the QOL on POW;

4) if the OSO mediates the QOL-POW relation, reducing the impact of the QOL on POW.

\section{METHOD}

\subsection{Participants}

The sample was made up of 1,292 participants from a public organization of the direct administration, with a population of 1,600 employees. All 
units of the organization are represented in the sample. The unit with the lowest number of participants counted on $49 \%$ of the total of the unit; $87 \%$ of the respondents held university degree, specialization, Master's degree, Doctor's degree; $70 \%$ were from the end area; $67.7 \%$ worked for more than 25 years in the organization.

\subsection{Instrument}

The research participants completed a questionnaire with questions about personal and functional demographic data, in addition to four scales: Scale of Quality of Organizational Life (SQOL), Scale of Personal Organizational Well-Being (SPOW), Organizational Culture Assessment Instrument (OCAI) and Scale of Organizational Styles of Operation (SOSO). Scales showed good indications of psychometric validity derived from previous studies with samples of professionals from public and private organizations (Paz, 2011; Paz \& Mendes, 2008; Paz et al., 2014). All scales that make up the instrument are 5-point scales, ranging from 0 to 4.

All instruments underwent the confirmatory factor analysis (CFA) (Kleine, 2015) and results showed high factor loading (all >0.40) and good reliability indexes measured through Cronbach's alpha.

\section{(Figure 5.2.1)}

CRONBACH'S ALPHA OF THE FACTORS OF SCALES USED

\begin{tabular}{lc}
\hline Scale of Quality of Organizational Life (SQOL) & $\alpha$ \\
\hline Work execution support & 0.888 \\
\hline Interpersonal relationship & 0.875 \\
\hline Respect & 0.826 \\
\hline Motivation to professional growth & 0.882 \\
\hline Awards & 0.891 \\
\hline Scale of Personal Organizational Well-being (SPOW) & $\alpha$ \\
\hline Professional fulfillment & 0.904 \\
\hline Working conditions & 0.862 \\
\hline
\end{tabular}




\section{(Figure 5.2.1 (conclusion))}

CRONBACH'S ALPHA OF THE FACTORS OF SCALES USED

\begin{tabular}{lc}
\hline Organizational Culture Assessment Instrument (OCAI) & $\alpha$ \\
\hline Clan culture & 0.883 \\
\hline Adhocracy & 0.843 \\
\hline Society & 0.855 \\
\hline Hierarchy & 0.802 \\
\hline Scale of Organizational Styles of Operation (SOSO) & $\alpha$ \\
\hline Affiliative & 0.867 \\
\hline Bureaucratic & 0.879 \\
\hline Entrepreneur & 0.886 \\
\hline Individualist & 0.860 \\
\hline
\end{tabular}

Source: Elaborated by the authors.

The results of the CFA showed suitability to the expected theoretical structure of each instrument, and all original factors were maintained (Figure 5.2.2). Models reached good levels to the Comparative Fit Index (CFI), Tucker Lewis Index (TLI), and Root-Mean-Square Error of Aproximation (RMSEA). In terms of SRMR (Standardized Root Mean Square Residual), only the POW presented index higher than the acceptable; however, this difference was as small as 0.001 .

\section{(Figure 5.2.2)}

OVERALL ADJUSTMENT TO THE QWL, POW, COV AND OSO

\begin{tabular}{ccccccccc}
\hline Models & $\chi^{2}$ & gl & $P$ & $\chi^{2} / \mathrm{gI}$ & CFI & TLI & RMSEA & SRMR \\
\hline OQL & 871.995 & 340 & $<0.001$ & 2.565 & 0.994 & 0.993 & 0.037 & 0.048 \\
\hline POW & 693.780 & 89 & $<0.001$ & 7.795 & 0.952 & 0.944 & 0.077 & 0.071 \\
\hline COV & 366.433 & 246 & $<0.001$ & 1.490 & 0.996 & 0.995 & 0.030 & 0.054 \\
\hline OSO & 396.277 & 183 & $<0.001$ & 2.165 & 0.980 & 0.977 & 0.045 & 0.063 \\
\hline
\end{tabular}

Source: Elaborated by the authors. 


\subsection{Data collection procedures}

The survey participants were invited to complete the instruments through internal publication on the organization Intranet. The researchers sent on the web and to all employees the link of access to the system used to collect data. Questionnaires could be accessed on any device connected to the Internet. Responses were stored in an external server used by the researchers with no interference from the organization.

All the survey participants completed the SQOL and SPOW questionnaires. In order to reduce the total number of items to be answered, the scales of organizational culture were applied to two groups: 1. the group of registration numbers ended in an odd number, completed the OCAI (642 respondents) and 2 . the group of registration numbers ended in an even number, completed the SOSO (650 respondents).

\subsection{Data analysis}

In the database cleaning on the four scales, missing data and outliers were analyzed through Z-score and Mahalanobis distance. Ten participants were withdrawn, and the sample was then made up by 1,292 respondents.

The analysis of assumptions to test the theoretical model was then performed. The Box' $M$ and Levene tests were performed and showed that variables present homocedasticity.

The normality test was also performed showing that no variable violated the criteria of symmetry and kurtosis simultaneously. This is an indication of normality: all variables adhered to the normal curve.

All variables comply with the assumption of linearity that was tested through scatterplot, added with a straight and measurement of the $\mathrm{R}^{2}$ value of linearity. The multicollinearity tests did not present significant multicollinearity indexes to the variables. Residues distribution was normal and amplitude showed good fitness of the model, i.e., the forecast proposed by the regression equations can be generalized to the population.

The comparison of equivalence between scales of macro level was done. The analyses of modeling through structural equations considered one model to each scale. The $\mathrm{R}^{2}$ resulting from analyses were all higher than 0.41 , suggesting that the analyses measure different constructs.

The intraclass correlation coefficient (ICC) corresponding to the measurement of the variance proportion attributable to each macro variable was calculated. Respondents were clustered at the level of units. The ICC measures to which extent the units can be differently reliable in terms of scores of individual dimensions. Results found are considered of small and moderate 
effects, ranging from 0.01 to 0.12 . According to the international literature, there is no prohibition regarding the aggregation of data (James, Demaree, \& Wolf, 1984).

Four models were statistically tested through analyses of regression to reflect the relations of culture mediation and moderation between QOL and POW. The moderation tests proposed to meet objectives 1 and 2 were performed, but, due to the lack of significant results to this sample, these are not described. Figure 5.4.1 presents both mediation models tested to achieve objectives 3 and 4 .

In order to understand the relations of the models variables, linear regression analyses were performed to verify: the relation of prediction of independent variables of QOL in relation to the dependent variables of POW; the relation of prediction of cultural variables OSO and COV, mediators in relation to variables of well-being; the relation of prediction of variables of quality of life in relation to the cultural variables.

The indirect and mediation effects were tested through multiple hierarchic regressions, according to Hayes (2017), to confirm if in the presence of the independent variable and the mediator the significant relation that existed between the dependent variable and the independent one decreases in magnitude.

\section{(Figure 5.4.1) \\ MEDIATION MODELS}

Model 1 tested if the

mediator variable COV

explains the relationship

between the antecedent

QOL and the consequent

PWO, since it neutralizes/

decreases the direct force

of QOL's impact on PWO.

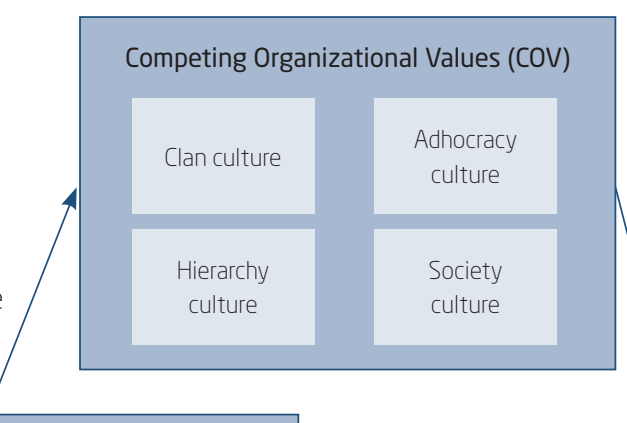

Quality of Organizational Life (QOL)

Work execution

support

Interpersonal

relationship

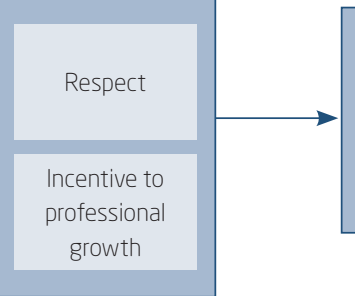

Personal Organizational Well-being (POW)
Work conditions 


\section{(Figure 5.4.1 (conclusion))}

\section{MEDIATION MODELS}

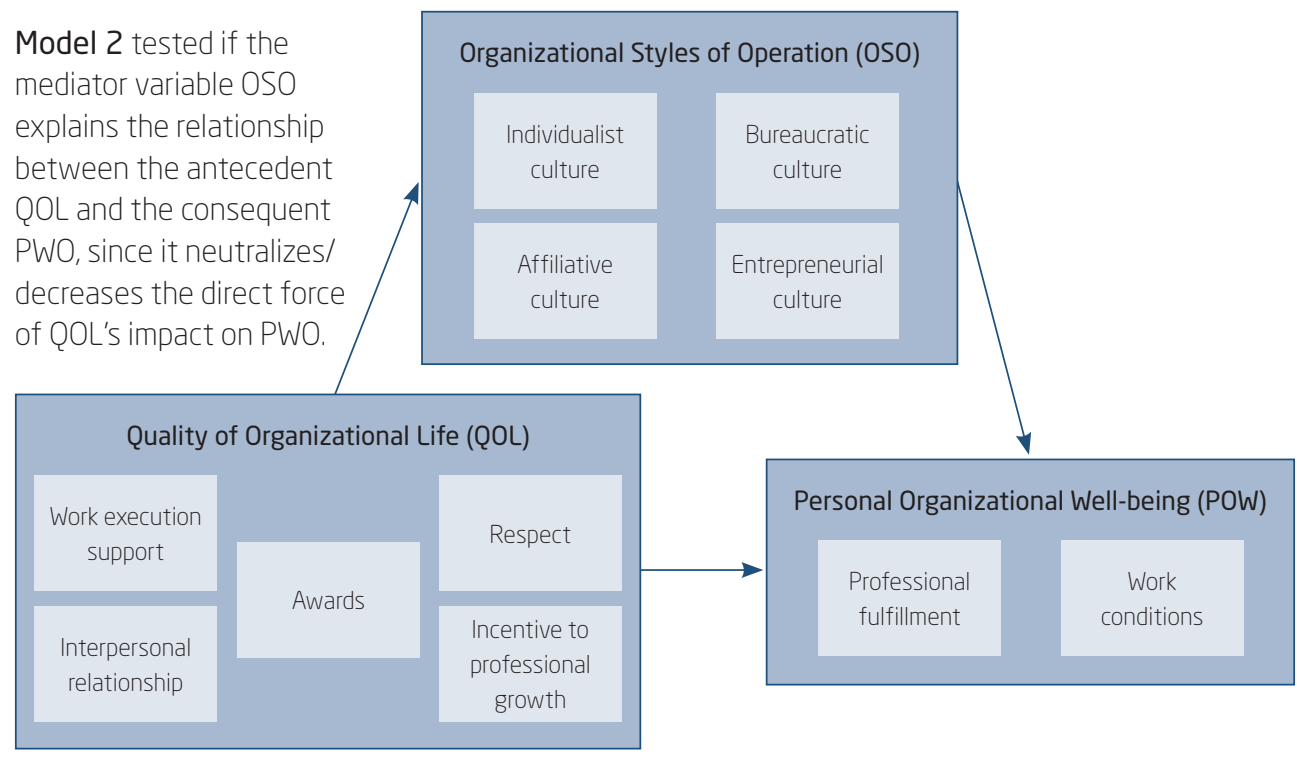

Source: Elaborated by the authors.

\section{RESULTS}

The linear regression analyses to confirm the relations of prediction of the QOL independent variables in relation to the POW dependent variables were all positive and significant $(\mathrm{p}<0.001)$.

The relations of prediction of the OSO and COV cultural variables, mediators, in relation to the POW variables were significant $(\mathrm{p}<0.001)$, except for the bureaucratic culture that predicted neither professional fulfillment nor work conditions. All the other cultural types showed their relations with the variables of well-being in a positive direction, except for the individualist culture.

The relations of prediction of the QOL variables in relation to the cultural variables were positive and significant $(p<0.001)$, except for the bureaucratic culture that was not predicted by any QOL variable, and the individualist culture to which predictions were significant, but negative.

After the preliminary analyses, the variable bureaucratic culture was withdrawn from the testing of mediation models, that were organized in 5 major groups in which each of the QOL independent variables are presented in relation to all other mediator variables (COV and OSO) and dependent 
variables (POW) (figures 6.1 a 6.5). The figures disclose the direct effect ( $\beta$ to the predictor variable without inserting the mediator variable) and the indirect effect ( $\beta$ to the predictor variable after inserting the mediator variable). The mediation effect is observed when $\beta$ is reduced in the comparison of the direct effect in relation to the indirect effect (Hayes, 2017).

Figure 6.1 suggests that all cultural types bound to the COV (clan, adhocracy, society and hierarchy cultures) are mediators between work execution support (QOL) and POW variables.

The mediation test to cultures related to the organization values shows that adhocracy culture is the strongest mediator between support and fulfillment in a positive direction (mediation effect - 0.529). In the presence of the adhocracy variable, the relation between support and fulfillment decreases in magnitude ( $\beta$ falls from 0.51 to 0.41 ) and the fulfillment explanation power increases $\left(\mathrm{R}^{2} 0.407\right.$ to 0.452$)$. The clan culture was the weakest mediator.

Regarding the OSO, the effect of mediation of entrepreneurial culture and fulfillment was the strongest one (0.491). In the presence of the entrepreneurial variable, the relation between support and fulfillment decreases in magnitude ( $\beta$ falls from 0.49 to 0.22 ) and the fulfillment explanation power increases $\left(\mathrm{R}^{2} 0.339\right.$ to 0.430$)$. The mediation effect of the individualist culture was the weakest one, in addition to the negative relation, suggesting that in the presence of individualist culture the negative relation between support and fulfillment decreases in magnitude and the explanation power of fulfillment increases.

\section{(Figure 6.1)}

HIERARCHIC LINEAR REGRESSION OF WORK EXECUTION SUPPORT (QOL) TO PREDICT THE POW FACTORS MEDIATED BY FACTORS OF COV AND OSO

\begin{tabular}{|c|c|c|c|c|}
\hline & Model variables & $\mathrm{R}^{2}$ & $\beta$ & Mediation effect \\
\hline \multicolumn{5}{|c|}{ Professional fulfillment } \\
\hline \multirow{7}{*}{$\frac{\mathscr{\varrho}}{\frac{N}{n}}$} & Direct & 0.407 & $0.51^{*}$ & - \\
\hline & Indirect & \multirow{2}{*}{0.498} & $0.27^{\star}$ & \multirow{2}{*}{0.396} \\
\hline & Clan & & $0.72^{\star}$ & \\
\hline & Indirect & \multirow{2}{*}{0.452} & $0.41^{*}$ & \multirow{2}{*}{0.529} \\
\hline & Adhocracy & & $0.68^{*}$ & \\
\hline & Indirect & \multirow{2}{*}{0.452} & $0.43^{\star}$ & \multirow{2}{*}{0.405} \\
\hline & Society & & $0.60^{*}$ & \\
\hline
\end{tabular}

(continue) 


\section{(Figure 6.1 (conclusion))}

HIERARCHIC LINEAR REGRESSION OF WORK EXECUTION SUPPORT (QOL) TO PREDICT THE POW FACTORS MEDIATED BY FACTORS OF COV AND OSO

\begin{tabular}{|c|c|c|c|c|}
\hline & Model variables & $\mathrm{R}^{2}$ & $\beta$ & Mediation effect \\
\hline \multicolumn{5}{|c|}{ Professional fulfillment } \\
\hline \multirow{2}{*}{$\frac{\text { さ }}{\stackrel{N}{J}}$} & Indirect & \multirow{2}{*}{0.459} & $0.42^{\star}$ & \multirow{2}{*}{0.419} \\
\hline & Hierarchy & & $0.57^{\star}$ & \\
\hline \multirow{7}{*}{ 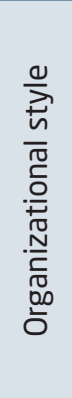 } & Direct & 0.339 & $0.49^{*}$ & - \\
\hline & Indirect & \multirow{2}{*}{0.379} & $0.38^{\star}$ & \multirow{2}{*}{0.377} \\
\hline & Affiliative & & $0.42^{\star}$ & \\
\hline & Indirect & \multirow{2}{*}{0.430} & $0.22^{\star}$ & \multirow{2}{*}{0.491} \\
\hline & Entrepreneurial & & $0.67^{\star}$ & \\
\hline & Indirect & \multirow{2}{*}{0.360} & $0.45^{\star}$ & \multirow{2}{*}{0.039} \\
\hline & Individualist & & $-0.26^{\star}$ & \\
\hline \multicolumn{5}{|c|}{ Work conditions } \\
\hline \multirow{9}{*}{$\frac{\text { ֻ }}{\stackrel{D}{J}}$} & Direct & 0.547 & $0.68^{\star}$ & - \\
\hline & Indirect & \multirow{2}{*}{0.579} & $0.54^{\star}$ & \multirow{2}{*}{0.208} \\
\hline & Clan & & $0.73^{*}$ & \\
\hline & Indirect & \multirow{2}{*}{0.565} & $0.58^{\star}$ & \multirow{2}{*}{0.262} \\
\hline & Adhocracy & & $0.68^{\star}$ & \\
\hline & Indirect & \multirow{2}{*}{0.559} & $0.61^{\star}$ & \multirow{2}{*}{0.211} \\
\hline & Society & & $0.60^{\star}$ & \\
\hline & Indirect & \multirow{2}{*}{0.583} & $0.56^{\star}$ & \multirow{2}{*}{0.237} \\
\hline & Hierarchy & & $0.57^{\star}$ & \\
\hline \multirow{7}{*}{ 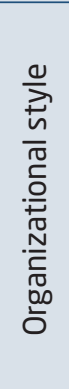 } & Direct & 0.505 & $0.62^{*}$ & - \\
\hline & Indirect & \multirow{2}{*}{0.515} & $0.57^{\star}$ & \multirow{2}{*}{0.229} \\
\hline & Affiliative & & $0.42^{\star}$ & \\
\hline & Indirect & \multirow{2}{*}{0.550} & $0.44^{\star}$ & \multirow{2}{*}{0.545} \\
\hline & Entrepreneurial & & $0.67^{\star}$ & \\
\hline & Indirect & \multirow{2}{*}{0.517} & $0.60^{*}$ & \multirow{2}{*}{0.080} \\
\hline & Individualist & & $-0.26 *$ & \\
\hline
\end{tabular}

${ }^{*} p<0.01$

Source: Elaborated by the authors 
The entrepreneurial culture was the strongest mediator between support and work conditions, mediation effect $(0.545)$. In the presence of the entrepreneurial culture, the relation between support and work conditions decreases in magnitude ( $\beta$ falls from 0.68 to 0.44 ) and the explanation power of work conditions increases (0.505 to 0.550$)$. The individualist culture was the weakest, in a negative relation.

Figure 6.2 points out that all cultural types bound to organizational values, as well as those related to the OSO, are mediators between interpersonal relationship (QOL) and personal fulfillment. Results show that, among values, the clan culture presents the strongest mediation effect between interpersonal relationships and fulfillment (0.480), and hierarchy shows the lowest mediation effect (0.280). As regards the OSO, the entrepreneurial culture is the strongest mediator (0.692) and the individualist culture is the weakest one, with low mediation power (0.097), in a negative relation.

In relation to mediation between interpersonal relationships and work conditions, all cultures related to values and all related to the style of operation are mediators. The entrepreneurial culture is the strongest mediator of this relation (0.593) among the OSO, and individualist culture is the weakest mediator (0.097) in a negative relation. Among cultures related to values, the clan culture was the strongest mediator (0.388) and society culture was the weakest (0.196). Results show that, in the presence of each mediating culture, the impact of interpersonal relationships on work conditions and fulfillment decreases, and the explanation power of the support variable on both variables increases, except for the individualist culture that has a negative mediation effect.

\section{(Figure 6.2) \\ HIERARCHIC LINEAR REGRESSION OF INTERPERSONAL RELATIONSHIP (QOL) TO PREDICT THE POW FACTORS MEDIATED BY FACTORS OF COV AND OSO}

\begin{tabular}{|c|c|c|c|c|}
\hline & Model variables & $\mathrm{R}^{2}$ & $\beta$ & Mediation effect \\
\hline \multicolumn{5}{|c|}{ Professional fulfillment } \\
\hline \multirow{3}{*}{$\frac{\mathscr{y}}{\frac{\mathfrak{J}}{J 0}}$} & Direct & 0.369 & $0.46^{\star}$ & - \\
\hline & Indirect & \multirow{2}{*}{0.472} & $0.24^{\star}$ & \multirow{2}{*}{0.480} \\
\hline & Clan & & $0.67^{\star}$ & \\
\hline
\end{tabular}


(Figure 6.2 (continuation))

HIERARCHIC LINEAR REGRESSION OF INTERPERSONAL RELATIONSHIP (QOL) TO PREDICT THE POW FACTORS MEDIATED BY FACTORS OF COV AND OSO

\begin{tabular}{|c|c|c|c|c|}
\hline & Model variables & $\mathrm{R}^{2}$ & $\beta$ & Mediation effect \\
\hline \multicolumn{5}{|c|}{ Professional fulfillment } \\
\hline \multirow{6}{*}{$\frac{\tilde{N}}{\frac{n}{N}}$} & Indirect & \multirow{2}{*}{0.436} & $0.32^{*}$ & \multirow{2}{*}{0.309} \\
\hline & Adhocracy & & $0.57^{\star}$ & \\
\hline & Indirect & \multirow{2}{*}{0.427} & $0.35^{\star}$ & \multirow{2}{*}{0.247} \\
\hline & Society & & $0.52^{\star}$ & \\
\hline & Indirect & \multirow{2}{*}{0.432} & $0.33^{\star}$ & \multirow{2}{*}{0.280} \\
\hline & Hierarchy & & $0.51^{\star}$ & \\
\hline \multirow{7}{*}{ 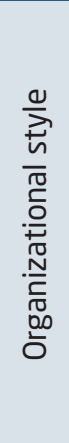 } & Direct & 0.270 & $0.39 *$ & - \\
\hline & Indirect & \multirow{2}{*}{0.313} & $0.27^{\star}$ & \multirow{2}{*}{0.306} \\
\hline & Affiliative & & $0.41^{\star}$ & \\
\hline & Indirect & \multirow{2}{*}{0.405} & $0.12^{\star}$ & \multirow{2}{*}{0.692} \\
\hline & Entrepreneurial & & $0.59^{\star}$ & \\
\hline & Indirect & \multirow{2}{*}{0.299} & $0.36^{\star}$ & \multirow{2}{*}{0.097} \\
\hline & Individualist & & $-0.23^{*}$ & \\
\hline \multicolumn{5}{|c|}{ Work conditions } \\
\hline \multirow{9}{*}{$\frac{\tilde{\coprod}}{\frac{\tilde{J}}{J}}$} & Direct & 0.411 & $0.52^{*}$ & - \\
\hline & Indirect & \multirow{2}{*}{0.477} & $0.32^{*}$ & \multirow{2}{*}{0.388} \\
\hline & Clan & & $0.67^{\star}$ & \\
\hline & Indirect & \multirow{2}{*}{0.469} & $0.37^{\star}$ & \multirow{2}{*}{0.282} \\
\hline & Adhocracy & & $0.57^{\star}$ & \\
\hline & Indirect & \multirow{2}{*}{0.446} & $0.42^{\star}$ & \multirow{2}{*}{0.196} \\
\hline & Society & & $0.52^{\star}$ & \\
\hline & Indirect & \multirow{2}{*}{0.48} & $0.37^{\star}$ & \multirow{2}{*}{0.295} \\
\hline & Hierarchy & & $0.51^{\star}$ & \\
\hline
\end{tabular}




\section{(Figure 6.2 (conclusion)) \\ HIERARCHIC LINEAR REGRESSION OF INTERPERSONAL RELATIONSHIP (QOL) TO PREDICT THE POW FACTORS MEDIATED BY FACTORS OF COV AND OSO}

\begin{tabular}{|c|c|c|c|c|}
\hline & Model variables & $\mathrm{R}^{2}$ & $\beta$ & Mediation effect \\
\hline \multicolumn{5}{|c|}{ Work conditions } \\
\hline \multirow{7}{*}{ 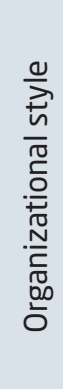 } & Direct & 0.319 & $0.45^{\star}$ & - \\
\hline & Indirect & \multirow{2}{*}{0.340} & $0.37^{\star}$ & \multirow{2}{*}{0.179} \\
\hline & Affiliative & & $0.41^{\star}$ & \\
\hline & Indirect & \multirow{2}{*}{0.447} & $0.18^{\star}$ & \multirow{2}{*}{0.593} \\
\hline & Entrepreneurial & & $0.59 *$ & \\
\hline & Indirect & \multirow{2}{*}{0.343} & $0.41^{\star}$ & \multirow{2}{*}{0.097} \\
\hline & Individualist & & $-0.23^{\star}$ & \\
\hline
\end{tabular}

$* p<0.01$.

Figure 6.3 indicates that clan, adhocracy, society and hierarchy cultures, as well as the affiliative, entrepreneurial and individualist cultures are mediators between respect (QOL) and personal fulfillment. Among values, the clan culture presents the strongest mediation effect between respect and fulfillment (0.365) and society culture shows the lowest mediation effect (0.198). As regards the OSO, the entrepreneurial culture is the strongest mediator (0.466) and the individualist culture is the weakest one (0.070), in a negative relation.

\section{(Figure 6.3)}

HIERARCHIC LINEAR REGRESSION OF RESPECT (QOL) TO PREDICT THE PWO FACTORS MEDIATED BY FACTORS OF COV AND OSO

\begin{tabular}{|c|c|c|c|c|}
\hline & Model variables & $\mathrm{R}^{2}$ & $\beta$ & Mediation effect \\
\hline \multicolumn{5}{|c|}{ Professional fulfillment } \\
\hline \multirow{5}{*}{$\frac{\tilde{d}}{\frac{\tilde{J}}{J}}$} & Direct & 0.431 & $0.55^{\star}$ & - \\
\hline & Indirect & \multirow{2}{*}{0.521} & $0.35^{*}$ & \multirow{2}{*}{0.365} \\
\hline & Clan & & $0.68^{\star}$ & \\
\hline & Indirect & \multirow{2}{*}{0.483} & $0.41^{*}$ & \multirow{2}{*}{0.246} \\
\hline & Adhocracy & & $0.62^{*}$ & \\
\hline
\end{tabular}




\section{(Figure 6.3 (conclusion))}

HIERARCHIC LINEAR REGRESSION OF RESPECT (QOL) TO PREDICT THE PWO FACTORS MEDIATED BY FACTORS OF COV AND OSO

\begin{tabular}{|c|c|c|c|c|}
\hline & Model variables & $\mathrm{R}^{2}$ & $\beta$ & Mediation effect \\
\hline \multicolumn{5}{|c|}{ Professional fulfillment } \\
\hline \multirow{4}{*}{$\frac{\tilde{N}}{\frac{n}{n}}$} & Indirect & \multirow{2}{*}{0.78} & $0.44^{\star}$ & \multirow{2}{*}{0.198} \\
\hline & Society & & $0.57^{\star}$ & \\
\hline & Indirect & \multirow{2}{*}{0.474} & $0.43^{*}$ & \multirow{2}{*}{0.217} \\
\hline & Hierarchy & & $0.58^{\star}$ & \\
\hline \multirow{7}{*}{ 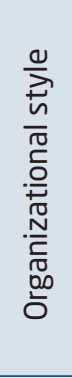 } & Direct & 0.365 & $0.51^{\star}$ & - \\
\hline & Indirect & \multirow{2}{*}{0.396} & $0.41^{*}$ & \multirow{2}{*}{0.199} \\
\hline & Affiliative & & $0.42^{\star}$ & \\
\hline & Indirect & \multirow{2}{*}{0.448} & $0.27^{\star}$ & \multirow{2}{*}{0.466} \\
\hline & Entrepreneurial & & $0.66^{\star}$ & \\
\hline & Indirect & \multirow{2}{*}{0.381} & $0.47^{\star}$ & \multirow{2}{*}{0.070} \\
\hline & Individualist & & $-0.29^{\star}$ & \\
\hline \multicolumn{5}{|c|}{ Work conditions } \\
\hline \multirow{9}{*}{$\frac{\tilde{N}}{\frac{n}{N}}$} & Direct & 0.492 & $0.64^{*}$ & - \\
\hline & Indirect & \multirow{2}{*}{0.546} & $0.47^{\star}$ & \multirow{2}{*}{0.260} \\
\hline & Clan & & $0.68^{\star}$ & \\
\hline & Indirect & \multirow{2}{*}{0.534} & $0.51^{*}$ & \multirow{2}{*}{0.195} \\
\hline & Adhocracy & & $0.62^{\star}$ & \\
\hline & Indirect & \multirow{2}{*}{0.517} & $0.55^{\star}$ & \multirow{2}{*}{0.132} \\
\hline & Society & & $0.57^{\star}$ & \\
\hline & Indirect & \multirow{2}{*}{0.536} & $0.51^{\star}$ & \multirow{2}{*}{0.203} \\
\hline & Hierarchy & & $0.58^{\star}$ & \\
\hline \multirow{7}{*}{ 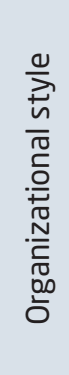 } & Direct & 0.421 & $0.57^{\star}$ & - \\
\hline & Indirect & \multirow{2}{*}{0.435} & $0.50 *$ & \multirow{2}{*}{0.118} \\
\hline & Affiliative & & $0.42^{*}$ & \\
\hline & Indirect & \multirow{2}{*}{0.499} & $0.34^{\star}$ & \multirow{2}{*}{0.407} \\
\hline & Entrepreneurial & & $0.66^{\star}$ & \\
\hline & Indirect & \multirow{2}{*}{0.433} & $0.54^{\star}$ & \multirow{2}{*}{0.551} \\
\hline & Individualist & & $-0.29^{*}$ & \\
\hline
\end{tabular}


There is a mediation relation between respect and work conditions of all cultures related to values and all related to style of operation. Among the OSO, the individualist culture is the strongest mediator of this relation (0.593) in a negative direction, and affiliative culture is the weakest mediator (0.118). Among cultures related to values, the clan culture was the strongest mediator (0.388) and society culture was the weakest one (0.196). Results show that, in the presence of each mediating culture, the impact of respect on the POW variables reduces and the relation between respect and fulfillment and respect and work conditions increases, except for the individualist culture that has a negative mediation effect.

Figure 6.4 presents the relations of mediation of the clan, adhocracy, society and hierarchy cultures, and of the entrepreneurial, affiliative and individualist cultures on the relation motivation to professional growth (QOL) and the POW variables. Results show that, among values, the clan culture presents the strongest mediation effect between motivation to grow and fulfillment (0.344), and society culture shows the lowest mediation effect (0.189). As regards the OSO, the entrepreneurial culture is the strongest mediator (0.574) and the individualist culture is the weakest one (0.076), with a negative relation.

\section{(Figure 6.4)}

HIERARCHIC LINEAR REGRESSION OF MOTIVATION TO GROW (QOL) TO PREDICT THE PWO FACTORS MEDIATED BY FACTORS OF COV AND OSO

\begin{tabular}{|c|c|c|c|c|}
\hline & Model values & $\mathrm{R}^{2}$ & $\beta$ & Mediation effect \\
\hline \multicolumn{5}{|c|}{ Professional fulfillment } \\
\hline \multirow{9}{*}{$\frac{\tilde{\varrho}}{\frac{\tilde{J}}{J}}$} & Direct & 0.442 & $0.50^{\star}$ & - \\
\hline & Indirect & \multirow{2}{*}{0.529} & $0.33^{\star}$ & \multirow{2}{*}{0.344} \\
\hline & Clan & & $0.60^{\star}$ & \\
\hline & Indirect & \multirow{2}{*}{0.488} & $0.38^{*}$ & \multirow{2}{*}{0.232} \\
\hline & Adhocracy & & $0.57^{*}$ & \\
\hline & Indirect & \multirow{2}{*}{0.489} & $0.41^{*}$ & \multirow{2}{*}{0.189} \\
\hline & Society & & $0.50^{\star}$ & \\
\hline & Indirect & \multirow{2}{*}{0.501} & $0.39 *$ & \multirow{2}{*}{0.213} \\
\hline & Hierarchy & & $0.47^{\star}$ & \\
\hline
\end{tabular}




\section{(Figure 6.4 (conclusion))}

HIERARCHIC LINEAR REGRESSION OF MOTIVATION TO GROW (QOL) TO PREDICT THE PWO FACTORS MEDIATED BY FACTORS OF COV AND OSO

\begin{tabular}{|c|c|c|c|c|}
\hline & Model values & $\mathrm{R}^{2}$ & $\beta$ & Mediation effect \\
\hline \multicolumn{5}{|c|}{ Professional fulfillment } \\
\hline \multirow{7}{*}{ 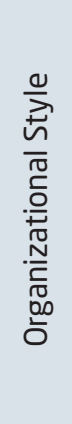 } & Direct & 0.343 & $0.45^{\star}$ & - \\
\hline & Indirect & \multirow{2}{*}{0.382} & $0.35^{\star}$ & \multirow{2}{*}{0.227} \\
\hline & Affiliative & & $0.39 *$ & \\
\hline & Indirect & \multirow{2}{*}{0.424} & $0.19^{\star}$ & \multirow{2}{*}{0.574} \\
\hline & Entrepreneurial & & $0.65^{\star}$ & \\
\hline & Indirect & \multirow{2}{*}{0.375} & $0.42^{*}$ & \multirow{2}{*}{0.076} \\
\hline & Individualist & & $-0.20^{\star}$ & \\
\hline \multicolumn{5}{|c|}{ Work conditions } \\
\hline \multirow{9}{*}{$\frac{\text { 凹 }}{\frac{J}{J}}$} & Direct & 0.496 & $0.57^{\star}$ & - \\
\hline & Indirect & \multirow{2}{*}{0.552} & $0.42^{\star}$ & \multirow{2}{*}{0.266} \\
\hline & Clan & & $0.60^{\star}$ & \\
\hline & Indirect & \multirow{2}{*}{0.531} & $0.46^{\star}$ & \multirow{2}{*}{0.196} \\
\hline & Adhocracy & & $0.57^{\star}$ & \\
\hline & Indirect & \multirow{2}{*}{0.52} & $0.49^{\star}$ & \multirow{2}{*}{0.138} \\
\hline & Society & & $0.50^{\star}$ & \\
\hline & Indirect & \multirow{2}{*}{0.558} & $0.45^{\star}$ & \multirow{2}{*}{0.216} \\
\hline & Hierarchy & & $0.47^{\star}$ & \\
\hline \multirow{7}{*}{ 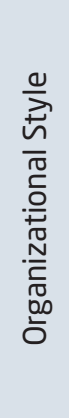 } & Direct & 0.434 & $0.53^{\star}$ & - \\
\hline & Indirect & \multirow{2}{*}{0.45} & $0.47^{\star}$ & \multirow{2}{*}{0.114} \\
\hline & Affiliative & & $0.39^{\star}$ & \\
\hline & Indirect & \multirow{2}{*}{0.492} & $0.31^{\star}$ & \multirow{2}{*}{0.401} \\
\hline & Entrepreneurial & & $0.65^{\star}$ & \\
\hline & Indirect & \multirow{2}{*}{0.46} & $0.50^{\star}$ & \multirow{2}{*}{0.059} \\
\hline & Individualist & & $-0.20^{*}$ & \\
\hline
\end{tabular}

${ }^{*} p<0.01$. 
There is a mediation relation between motivation to grow and work conditions of all cultures related to values and all related to the style of operation. Among the OSO, the entrepreneurial culture is the strongest mediator of this relation (0.401) and the individualist culture is the weakest one (0.059). Among cultures related to values, the clan culture was the strongest mediator $(0.266)$ and society culture was the weakest one $(0.138)$. Results show that in the presence of each of the mediating cultures, the impact of motivation to grow on fulfillment and work conditions decreases, but the power of explanation of the relation between motivation to grow and fulfillment, and also with work conditions increases.

Figure 6.5 presents de mediation relations of the clan, adhocracy, society and hierarchy cultures, and of the entrepreneurial, affiliative and individualist cultures on the relation awards (QOL) and fulfillment (POW), and awards (QOL) and work conditions (POW). Results show that, among values, the clan culture presents the strongest mediation effect between awards and fulfillment (0.392), and society culture shows the lowest mediation effect (0.126). As regards the OSO, the entrepreneurial culture has strongest mediation power (0.617) and individualist culture has the lowest mediation power (0.078), in a negative relation.

\section{(Figure 6.5)}

HIERARCHIC LINEAR REGRESSION OF AWARD (QOL) TO PREDICT THE PWO FACTORS MEDIATED BY FACTORS OF COV AND OSO

\begin{tabular}{|c|c|c|c|c|}
\hline & Model variables & $\mathrm{R}^{2}$ & $\beta$ & Mediation effect \\
\hline \multicolumn{5}{|c|}{ Professional fulfillment } \\
\hline \multirow{9}{*}{$\frac{\tilde{d}}{\frac{n}{5}}$} & Direct & 0.403 & $0.53^{\star}$ & - \\
\hline & Indirect & 0.494 & $0.32^{\star}$ & \multirow{2}{*}{0.392} \\
\hline & Clan & - & $0.70^{*}$ & \\
\hline & Indirect & 0.453 & $0.40^{\star}$ & \multirow{2}{*}{0.257} \\
\hline & Adhocracy & - & $0.67^{*}$ & \\
\hline & Indirect & 0.45 & $0.54^{\star}$ & \multirow{2}{*}{0.126} \\
\hline & Society & - & $0.61^{*}$ & \\
\hline & Indirect & \multirow{2}{*}{0.462} & $0.41^{*}$ & \multirow{2}{*}{0.234} \\
\hline & Hierarchy & & $0.56^{\star}$ & \\
\hline
\end{tabular}




\section{(Figure 6.5 (conclusion))}

HIERARCHIC LINEAR REGRESSION OF AWARD (QOL) TO PREDICT THE PWO FACTORS MEDIATED BY FACTORS OF COV AND OSO

\begin{tabular}{|c|c|c|c|c|}
\hline & Model variables & $\mathrm{R}^{2}$ & $\beta$ & Mediation effect \\
\hline \multicolumn{5}{|c|}{ Professional fulfillment } \\
\hline \multirow{7}{*}{ 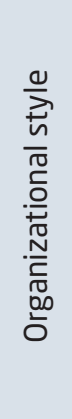 } & Direct & 0.336 & $0.48^{\star}$ & - \\
\hline & Indirect & 0.369 & $0.37^{\star}$ & \multirow{2}{*}{0.233} \\
\hline & Affiliative & - & $0.45^{\star}$ & \\
\hline & Indirect & \multirow{2}{*}{0.418} & $0.18^{\star}$ & \multirow{2}{*}{0.617} \\
\hline & Entrepreneurial & & $0.72^{\star}$ & \\
\hline & Indirect & \multirow{2}{*}{0.369} & $0.44^{*}$ & \multirow{2}{*}{0.078} \\
\hline & Individualist & & $-0.21^{\star}$ & \\
\hline \multicolumn{5}{|c|}{ Work conditions } \\
\hline \multirow{9}{*}{$\frac{\text { 凹 }}{\frac{J}{J}}$} & Direct & 0.484 & $0.62^{\star}$ & - \\
\hline & Indirect & \multirow{2}{*}{0.533} & $0.45^{\star}$ & \multirow{2}{*}{0.275} \\
\hline & Clan & & $0.70^{\star}$ & \\
\hline & Indirect & \multirow{2}{*}{0.514} & $0.50^{\star}$ & \multirow{2}{*}{0.192} \\
\hline & Adhocracy & & $0.67^{\star}$ & \\
\hline & Indirect & \multirow{2}{*}{0.502} & $0.54^{\star}$ & \multirow{2}{*}{0.126} \\
\hline & Society & & $0.61^{\star}$ & \\
\hline & Indirect & \multirow{2}{*}{0.537} & $0.49^{\star}$ & \multirow{2}{*}{0.220} \\
\hline & Hierarchy & & $0.56^{\star}$ & \\
\hline \multirow{7}{*}{ 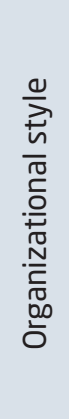 } & Direct & 0.417 & $0.56^{\star}$ & - \\
\hline & Indirect & \multirow{2}{*}{0.43} & $0.50^{\star}$ & \multirow{2}{*}{0.111} \\
\hline & Affiliative & & $0.45^{\star}$ & \\
\hline & Indirect & \multirow{2}{*}{0.478} & $0.31^{\star}$ & \multirow{2}{*}{0.453} \\
\hline & Entrepreneurial & & $0.72^{\star}$ & \\
\hline & Indirect & \multirow{2}{*}{0.445} & $0.53^{*}$ & \multirow{2}{*}{0.062} \\
\hline & Individualist & & $-0.21^{*}$ & \\
\hline
\end{tabular}

* $p<0.01$ 
There was mediation between award and work conditions of all cultures related to values and all cultures related to style of operation. Among the OSO, the entrepreneurial culture is the strongest mediator of this relation (0.453), and the individualist culture is the weakest one (0.062). Among cultures related to values, the clan culture was the strongest mediator (0.275) and society culture was the weakest (0.126). Results show that in the presence of each mediating culture the relation between award and fulfillment, and award and work conditions increases, except for the individualist culture that has a negative mediation effect, and the impact of awards on fulfillment and work conditions decreases.

In brief, results show that cultural dimensions of organizations are important mediators between QOL and POW, except for the bureaucratic culture that had no predictive power to the POW variables neither was predicted by the QOL variables. Meeting the three requirements to perform the mediation test, we find that: 1) when cultures are considered as protagonist of the COV (clan, adhocracy, society and hierarchy cultures) and also have the OSO characterized as affiliative, entrepreneurial and individualist cultures, people that make it up and share ways of feeling, thinking and acting typical to each of them, consider they experience well-being, even if in different forms: cultural variables predict well-being; 2) when the QOL factors, work execution support, interpersonal relationship, respect, motivation to grow and awards impact all cultural types retained in the model, but with different prediction power, i.e., they subsidize a positive and healthy environment in organizations, but in different ways due to the differentiation of cultural types - the QOL independent variables affect the cultural types; 3) finally, regarding the third condition, the seven cultural variables tested in the model mediate the relation between five QOL variables and two of POW.

\section{DISCUSSION AND CONCLUSION}

The results of the survey confirm the seven cultural variables of the model as mediators of the relation among all QOL and POW dimensions. Warr's (2007) statement that the organizational environment affects the employee well-being is ratified. The types of culture identified in both models proposed could characterize the culture and subcultures focused (Shein, 1992), favoring the possibility of adjustments to intervention programs that fit into specificities. The mediation power of organizational culture to explain the QOL-POW relation is worth of notice, and emphasizes 
the contribution of this study as it allows understanding the need for considering the organization cultural profile in the promotion of actions of change that ensure the QOL to enhance the worker's personal experience of well-being.

The test of model 1 supports the concerns of Quinn et al. (2011) when they emphasize the need for identifying the cultural traits to define organizational management strategies, by showing that the strength of QOL impact on POW is reduced when culture mediates the relation. The clan culture was the strongest mediator between all the QOL variables and those of well-being. According to Cameron and Quinn (1999), who characterize all cultural types based on competing values, clan is oriented to its community and its dynamicity. The operation as tribe is noticeable in this type of culture that appraises more affective interpersonal relationships. Although clan mediated all dimensions of QOL and well-being, its strongest mediation effect was between interpersonal relationships (QOL) and professional fulfillment (POW). There was a decrease in the impact of relationships on fulfillment, and increased power of explanation of fulfillment. In practice, the results found in this survey show that the organization that emphasizes interpersonal relationships as a managerial policy and has a clan culture increases more the professional fulfillment, a well-being dimension, than other cultural types.

The hierarchy, adhocracy and society cultures also mediated all relations between the QOL and well-being dimensions, but with less power than clan. Adhocracy reflects the values of the open systems model focused on the interaction organization / external environment, values stimulation and autonomy, and demands work execution support. The society culture reflects commitment with the establishment of clear and objective targets. It is a culture with external orientation, concerned about articulating with the social context in which it is inserted and interacting with. The organizational goals are translated into social results. Hierarchy is a cultural type with little flexibility, concerned about stability and predictability, which seeks efficiency, smooth operation and on-time delivery. The same phenomenon of reduced impact of all the QOL dimensions on the POW dimensions happened with the mediation of all cultural types related to values. The interpretation should follow the same explanatory logic of the relation clan culture, interpersonal relationship and professional fulfillment, considering the characterization of the cultural types.

As regards the test of model 2, among the mediation relations confirmed by the hierarchical regressions in relation to the OSO, the entrepreneurial 
culture was the strongest mediator between the QOL and POW variables. This culture mediated the relation between work execution support, interpersonal relationship, respect, motivation to grow, award and professional fulfillment, POW variable. It was also stronger in the mediation of the QOL variables and those of work conditions (POW), except when work execution support (QOL) was the predictor variable. This mediating power suggests that QOL variables reduce the impact on POW when the organizational culture is entrepreneurial.

Paz and Mendes (2008) characterize the OSO-related cultural types. Entrepreneurial cultures are characterized for valuing innovation. The issue of rights and duties between the individual and the organization is the focus of attention. People like challenges and obey rules even when they do not consider these rules as perfect. This could facilitate the processes of change. Since this culture is more realistic, it can better balance the personal and organizational expectations because it admits fallibility. Organizations with these cultural traits are likely to understand more deeply the need for fulfilling their commitments with the organization to make it grow and develop with more balanced reciprocity relations, thus promoting greater well-being.

The mediation power of the individualist culture among the QOL and the POW variables, although significant, is very small, except for the relation between the variable of respect (QOL) and the variable of work conditions (POW) whose mediation power, in a negative direction, was the highest among all cultural types. The individualist style characterizes a culture that emphatically meets the needs of admiration and centrality of its members. These are people that establish socio-professional relationships focused on their own ego and, therefore, want the requests at work to be more at a personal than at a professional level. As the pursue for well-being implies behaviors focused on the concern about the self, and the QOL variables derive from organizational policies oriented to the collective, it is likely that as more present the QOL variables are in this culture, the lower is the wellbeing of individualists that want exclusive and differentiated services, as they believe they are special.

Other cultural types that also characterize the OSO were mediators between the QOL and POW variables, although with weaker power. In the affiliative cultures, the organization members abide by the rules without questioning; they need to belong to the group. As ideology is a strong component, the environment is more homogeneous and contributes to personal fulfillment. The direct impact of the QOL variables on the POW 
variables is reduced when affiliative cultures are mediators, but the total power of explanation of the relation between QOL and POW increases.

The mediation effect of the clan, hierarchy, society and adhocracy cultures, and of the entrepreneurial, affiliative and individualist cultures is stronger in the relation between the QOL variables and professional fulfillment than between QOL and work conditions. Although work conditions are evaluated based on the respondents' perception, this result could be an indicator of what is proposed by Shulte and Vainio (2010), i.e., that wellbeing is more focused on the individual than on the organization. As the variable professional fulfillment focuses on well-being in a more subjective perspective, we could admit that this dimension is the most central dimension of the POW. This could be an indication that professional fulfillment is more relevant to well-being, as it depends more on the individual, while well-being referring to work conditions seems to depend more on the organization, but it does not mean it is not crucial for the personal well-being.

This study is original, since no test of similar models could be found in literature, thus preventing the comparison of its results with the results of other surveys. However, besides empirically evidencing the mediation power of culture, this survey points out, more generally, to the same direction as the results of the surveys by Dessen and Paz (2010), Choi et al. (2015) and Pilch and Turiska (2015) that tested models having culture and well-being as variables, although not having cultural variables as mediators. The result of the last three surveys mentioned showed significant role of cultural variables to explain the relations investigated in the models tested.

We conclude that the results found contribute to explain the relation of quality of life, culture and well-being in organizations. Notably, they confirm a good power of mediation of organizational cultures that, in this sample, reduced the influence of QOL on POW, but increased the power of explanation on well-being. Some cultures are stronger mediators of this relation than others. This leads us to agree with Noblet and La Montagne (2009), when they emphasize that interventions should be similar to the planning of organizational change programs that are dynamic and influenced by contextrelated factors. The organizational culture would be one of them.

Finally, it is worth emphasizing that the model should be tested in other organizations. The case study is a limitation of the survey as well as of the transversal study to test mediation. The application of instruments in a larger number of organizations using other kinds of statistic analyses, longitudinal and mixed studies would allow a better understanding of cultures as important macro organizational variables to implement policies and guidelines that ensure quality of life and well-being in organizations. 


\section{BEM-ESTAR PESSOAL NAS ORGANIZAÇÕES E QUALIDADE DE VIDA ORGANIZACIONAL: O PAPEL MEDIADOR DA CULTURA ORGANIZACIONAL}

\section{RESUMO}

Objetivo: Testar modelos de mediação e moderação da cultura organizacional, valores concorrentes e estilos de funcionamento organizacional, tendo como antecedente a qualidade de vida organizacional (QVO) e como consequente o bem-estar pessoal nas organizações (BEO).

Originalidade/valor: A literatura tem apresentado testes de modelos de mediação/moderação para compreender o bem-estar dos empregados e subsidiar a gestão para a implantação de estratégias adequadas às realidades organizacionais. A cultura organizacional tem sido variável componente de alguns desses modelos, mas não foram identificadas na literatura publicações que investiguem a cultura como mediadora/moderadora da relação qualidade de vida/bem-estar.

Design/metodologia/abordagem: Trata-se de pesquisa quantitativa, transversal, em que se utilizaram escalas que apresentam evidências de validade psicométrica. Essas escalas foram aplicadas a 1.292 empregados (81\%) da população de uma organização pública. Dois modelos de mediação e dois de moderação foram testados por meio de regressão múltipla.

Resultados: Os resultados das análises de regressão linear e hierárquica utilizadas para testar os modelos propostos revelaram que, com exceção da cultura burocrática, todos os tipos de cultura tiveram poder de mediação significativos entre as variáveis de QVO e BEO. Não foram identificadas relações de moderação. As evidências empíricas dos testes dos modelos indicam que é preciso atentar para as características culturais das organizações na definição de estratégias de intervenção relativas à $\mathrm{QVO}$ e ao BEO, visto que algumas podem ser mais aplicáveis a determinadas culturas e menos a outras.

\section{$\int$ PALAVRAS-CHAVE}

Qualidade de vida organizacional. Bem-estar. Cultura. Mediação. Modelo. 


\section{REFERENCES}

Akter, K. M., \& Banik, S. (2018). Factors affecting the quality of work into the RGM industry of Bangladesh. Journal of Human Resource Management, 6(1) 26-36. doi:10.11648/j.jhrm.20180601.14

Bartels, A. L., Peterson, S. J., \& Reina, C. S. (2019). Understanding wellbeing at work: Development and validation of the eudaimonic workplace well-being scale. PLOS ONE, 14(4), e0215957. doi:10.1371/journal. pone.0215957

Biron, C., Karanika-Murray, M., \& Cooper, C. (2012). Improving organizational interventions for psychosocial stress and well-being. New York: Routledge.

Boas, A. A. V., \& Morin, E. M. (2017). Qualidade de vida no trabalho: Um modelo de sistêmico de análise. Revista Administração em Diálogos, 19(2), 62-90. doi:10.20946/rad.v19i2.31720

Cameron, K., \& Quinn, R. E. (1999). Diagnosing and changing organizational culture. New York: Addison-Wesley.

Campos, M. I., \& Rueda, F. J. M. (2017). Effects of organizational values over quality of work life. Paidéia, 27(67), 65-75. doi:10.1590/1982-43272 767201708

Carneiro, L. L., \& Fernandes, S. R. P. (2015). Bem-estar pessoal nas organizações e lócus de controle no trabalho. Revista Psicologia: Organizações e Trabalho, 15(3), 257-270. doi:10.17652/rpot/2015.3.599

Choi, D., Oh, I.-S., \& Colbert, A. E. (2015). Understanding organizational commitment: A meta-analytic examination of the roles of the five-factor model of personality and culture. Journal of Applied Psychology, 100(5), 1542-1567. doi:10.1037/ap10000014

Cooper, C. L., Yipenge, L., \& Tarba, S. Y. (2014). Resilience, HRM practices and impact on organizational performance and employee well-being. International Journal of Human Resource Management, 25, 2466-2471. doi:10. 1080/09585192.2014.926688

Dessen, M. C., \& Paz, M. G. T. (2010). Bem-estar pessoal nas organizações: O impacto das configurações de poder e características de personalidade. Psicologia: Teoria e Pesquisa, 26(3), 549-556. doi:10.1590/s0102-377220 10000300018

Diener, E. (1984) Subjective well-being. Psychological Bulletin, 95(3), 542575. doi:10.1037//0033-2909.95.3.542 
Diener, E. (2000). Subjective well-being: The science of happiness and a proposal for a national index. American Psychologist, 55 (1), 34-43. doi:10.10 37//0003-066x.55.1.34

Elyzur, D., \& Shye, S. (1990). Quality of work life and its relation to quality of life. Applied Psychology: An International Review, 39(3), 275-291. doi:10.11 11/j.1464-0597.1990.tb01054.x

Guareshi, P. A. (2002). Psicologia social contemporânea. Petrópolis: Vozes.

Guest, D.E. (2017). Human resource management and employee well-being: Towards a new analytic framework. Human Resource Management Journal, 27(1), 22-38. doi:10.1111/1748-8583.12139

Hannif, Z., Burguess, J., \& Cornell, J. (2008). Call centers and the quality of work life: Towards a research agenda. Journal of Industrial Relations, 50(2), 271-284. doi:10.1177/0022185607087902

Hayes, A. F. (2017). Introduction to mediation, moderation, and conditional process analysis. New York: The Guilford Press.

Hillage, J., Brown, G., Shiels, C., \& Gabbay, M. (2014). Health and employment outcomes: Data exploration. London: The National Archives.

International Labour Organization (1981). Convention n. 155 -Occupational Safety and Health Convention. Retrieved from http://www.ilo.org/ilolex/ portug/docs/convdisp1.htm

James, L. R., Demaree, R. G., \& Wolf, G. (1984). Estimating within-group interrater reliability with and without response bias. Journal of Applied Psychology, 69, 85-89.

Juniper, B., Bellamy, P., \& White, N. (2011). Testing the performance of a new approach to measuring employee well-being. Leadership \& Organizations Development Journal, 32 (4), 344-357. doi:10.1108/01437731111134634

Kline, R. B. (2015). Principles and practice of structural equation modeling. New York: The Guilford Press.

Mintzberg, H. (1983). Power in and around organizations. Englewood Cliffs: Prentice Hall.

Nanjundeswaraswamy, T. S., \& Swamy, D. R. (2015). An empirical research on the relationship between quality of work life and leadership styles in SMEs. Bangladesh e-Journal of Sociology, 5(1), 65-78. doi:10.5267/j.msl. 2014.12.006

Noblet, A., \& LaMontagne, A. (2009). The challenges of developing, implementing, and evaluating interventions. In S. Cartwright \& C. L. Cooper (Eds.). The Oxford handbook of organizational well-being (pp. 466-496). Oxford: Oxford University Press. 
Paz, M. G. T. (2011). Perfil cultural de las organizaciones y bienestar del trabajador. In E. Aguilló, J. L. Álvaro, A. Garrido, \& I. S. Gallo (Eds.). Nuevas formas de organización del trabajo y la empleabilidad (pp. 85-108). Ovideo: Ediciones da la Universidad de Oviedo.

Paz, M. G. T., Melo, E. A. A., Tonet, H., \& Villa, N. (2014). Perfil cultural da ALMG. Brasília: Quântica Consultoria.

Paz, M. G. T., \& Mendes, A. M. B. (2008). Estilos de funcionamento organizacional. In M. M. M. Siqueira (Org.). Medidas do comportamento organizacional (pp. 162-178). Porto Alegre: Artmed.

Pilch, I., \& Turiska, E. (2015). Relationships between Machiavellianism, organizational culture and workplace bullying: Emotional abuse from the target's and the perpetrator's perspective. Journal of Business Ethics, 128(1), 83-93. doi:10.1007/s10551-014-2081-3

Quinn, R. E., Faerman, S. R., Thompson, M. P., McGrath, M. R., \& Clair, L. S. S. T. (2011). Becoming a master manager. New York: John Wiley \& Sons.

Ribeiro, P. E. C. D., Paz, M. G. T., Caldas, L. S., \& Santos, P. S. (2012). Construção e validação de uma escala de qualidade de vida organizacional. Resumos do Simpósio sobre Comportamento Organizacional, Lisboa, Portugal, 7.

Robertson, I., Cooper, C. L., Sarkar, M., \& Curran, T. (2015). Resilience training in the workplace from 2003-2014: A systematic review. Journal of Occupational and Organizational Psychology, 88(3), 533-562. doi:10.1111/ joop. 12120

Ryff, C. D. (1989). Happiness is everything, or is it? Explorations on the meaning of psychological well-being. Journal of Personality and Social Psychology, 57(6), 1069-1081. doi:10.1037//0022-3514.57.6.1069

Ryff, C. D. (2014). Psychological well-being revisited: Advances in the science and practice of eudaimonia. Psychotherapy and Psychosomatics, 83 (1), 10-28. doi:10.1159/000353263

Schein, E. H. (1992). Organizational culture and leadership (2nd ed.). San Francisco: Jossey-Bass.

Schneider, B., Ehrhart, M. G., \& Macey, W. H. (2013). Organizational climate and culture. Annual Review of Psychology, 64(1), 361-388. doi:10.1146/ annurev-psych-113011-143809

Shulte, P., \& Vainio, H. (2010). Well-being at work: Overview and perspective. Scandinavian Journal of Work and Environmental Health, 36(5), 422-429. doi:10.5271/sjweh.3076 
Sonnentag, S. (2015). Dynamics of well-being. Annual Review for Organizational Psychology and Organizational Behavior, 2, 261-293. doi:10.1146/annurevorgpsych-032414-111347

Sousa-Silva, J.(2003) A mudança de época e contexto global cambiante. In S. M. V. Lima (Org.). Mudança organizacional: Teoria e gestão (pp. 65-110). Rio de Janeiro: FGV.

Swamy, D. R., Nanjundeswaraswamy, T. S., \& Rashmi, S. (2015) Quality of work life: Scale development and validation. International Journal of Caring Sciences, 8(2), 281-295.

United Nation (1948). Universal Declaration of Human Rights. Retrieved from http://www.unhchr.ch/udhr/lang/por.htm

United Nations Development Programme (2005). Los derechos humanos en el PNUD: nota práctica. Retrieved from http://www.undp.org/ governance/docs/HRPN_Spanish.pdf

Van Horn, J. E., Taria, T. W., Scchaufeli, W. B., \& Scheurs, P. J. (2004). The structure of occupational well-being: A study among Dutch teachers. Journal of Occupational and Organizational Psychology, 77(3), 365-375. doi:10.1348/0963179041752718

Walton, R. E. (1973). Quality of work life: What is it? Sloan Management Review, 15, 11-21.

Warr, P. (1987). Work, unemployment and mental health. New York: Oxford University Press.

Warr, P. (2007). Work, happiness and unhappiness. New Jersey: Lawrence Erbaum Associates.

\section{AUTHOR NOTES}

Maria G. T. Paz, Ph.D. by the Institute of Psychology, São Paulo University (USP); Sonia R. P. Fernandes, PhD by the Institute of Public Health, Federal University of Bahia (Ufba); Laila L. Carneiro, PhD by the Institute of Psychology, Federal University of Bahia (Ufba); Eleuní A. A. Melo, PhD by the Institute of Psychology, Brasília University (UnB).

Maria G. T. Paz is now professor at the Institute of Psychology of Brasília University (UnB); Sonia R. P. Fernandes is now professor at the Institute of Psychology of Federal University of Bahia (Ufba); Laila L. Carneiro is now professor at the Institute of Psychology of Federal University of Bahia (Ufba); Eleuní A. A. Melo is now outside consultant.

Correspondence concerning this article should be addressed to Maria G. T. Paz, Campus Universitário Darcy, ICC Ala Sul, Asa Norte, Brasília, Distrito Federal, Brazil, CEP 70910-000.

E-mail: torrespaz@uol.com.br 
Personal organizational well-being and quality of organizational life: The mediating role of organizational culture

\section{EDITORIAL BOARD}

Editors-in-chief

Janette Brunstein

Silvia Marcia Russi De Domênico

Associated Editor

Sônia Maria Guedes Gondim

Technical Support

Vitória Batista Santos Silva

\section{EDITORIAL PRODUCTION}

Publishing Coordination

Jéssica Dametta

Layout Designer

Emap

\section{Editorial Intern}

Paula Di Sessa Vavlis

Graphic Designer

Libro
Language Editor

Daniel de Almeida Leão 